\begin{tabular}{|c|c|}
\hline Title & Sul phate climate coupling over the past 300,000 years in inland A ntarctica \\
\hline Author(s) & $\begin{array}{l}\text { lizuka, Y oshinori; U emura, Ryu; Motoyama, Hideaki; Suzuki, Toshitaka; Miyake, Takayuki; Hirabay ashi, Motohiro; } \\
\text { Hondoh, T akeo }\end{array}$ \\
\hline Citation & $\begin{array}{l}\text { Nature, 490(7418), 81-84 } \\
\text { https://doi.org/10.1038/hature11359 }\end{array}$ \\
\hline Issue Date & 2012-10-04 \\
\hline Doc URL & http:/hdl. handle.net/2115/52663 \\
\hline Type & article (author version) \\
\hline Additional Information & There are other files related to this item in HUSCAP. Check the above URL. \\
\hline File Information & Nat490-7418_81-84.pdf \\
\hline
\end{tabular}

Instructions for use 


\section{Sulphate-climate coupling over the past 300,000 years in inland Antarctica}

Yoshinori Iizuka1, Ryu Uemura2, Hideaki Motoyama3, Toshitaka Suzuki4, Takayuki Miyake3,5, Motohiro Hirabayashi3 and Takeo Hondoh1

1 Institute of Low Temperature Science, Hokkaido University, Sapporo 060-0819, Japan

2 Department of Chemistry, Biology and Marine Science, Faculty of Science, University of the Ryukyus, Okinawa 903-0213, Japan

3 National Institute of Polar Research, Tokyo 190-8518, Japan

4 Department of Earth and Environmental Sciences, Faculty of Science, Yamagata University, Yamagata 990-8560, Japan

5 now at: School of Environmental Science, The University of Shiga Prefecture, Shiga, 522-8533, Japan 
Sulphate aerosols, particularly micron-sized particles of sulphate salt and sulphate-adhered dust, can act as cloud condensation nuclei (CCN), leading to increased solar scattering that cools Earth's climate ${ }^{1-2}$. Global climate, according to the "CLAW" hypothesis ${ }^{3}$, may be regulated by marine phytoplankton in a negative feedback loop composed of temperature, cloud albedo, and sulphate production. Evidence for such sulphate-climate coupling in the current era has not been found ${ }^{4}$, but may be revealed in the long-term sulphate record from polar ice cores. Melted ice-core samples have previously provided only sulphate-ion concentrations, which may be due to sulphuric acid $^{5}$. Here we present profiles of sulphate-salt fluxes over the past 300,000 years from the Dome Fuji ice core in inland Antarctica. Results show a nearly constant flux of sulphate-adhered dust through glacial and interglacial periods despite large increases of dust flux during glacial maxima ${ }^{6}$. The sulphate-salt flux, however, correlates inversely with temperature, suggesting a climatic coupling between particulate sulphur and temperature. For example, the total sulphate-salt flux during the last glacial maximum averages $5.78 \mathrm{mg} \mathrm{m}^{-2} \mathrm{yr}^{-1}$, twice that of the $2.93 \mathrm{mg} \mathrm{m}^{-2} \mathrm{yr}^{-1}$ during the present Holocene. Although based on a model with serious uncertainties when applied to the ice core record, this analysis indicates that the glacial-to-interglacial decrease in sulphate would lessen the aerosol indirect effects on cloud albedo, leading to an Antarctic warming of 0.1 to 5.2 K. Our results provide further evidence against the CLAW hypothesis: although marine sulphur production does influence sulphate-salt flux during glacial maxima, $\mathrm{SO}_{4}{ }^{2-}$ 
remains constant when, according to CLAW, it should decline.

Climate of the last 430 kiloyear (kyr) is guided by large-amplitude 100-kyr glacial-interglacial cycles ${ }^{7}$. The glacial-interglacial cycles are triggered by the Earth's orbital changes, and then amplified by various land-atmospheric responses ${ }^{1}$. Of these responses, the influence from aerosol radiative forcing ${ }^{1}$ is particularly hard to accurately quantify. The low aerosol concentrations of the southern high-latitude region makes the direct effect of aerosol radiative forcing negligible, but the indirect effect, in which the aerosol acts as $\mathrm{CCN}$, could be significant ${ }^{8,9}$. Many $\mathrm{CCN}$ consist of sulphate salt, either by itself or mixed with silicate materials (Fig. S1) ${ }^{8}$, which can be preserved in the ice after precipitating to the ground.

Aerosols in the Antarctic region contain little anthropogenic and ammonium sulphates ${ }^{10}$, instead being dominated by sulphuric acid $\left(\mathrm{H}_{2} \mathrm{SO}_{4}\right)$, sodium sulphate $\left(\mathrm{Na}_{2} \mathrm{SO}_{4}\right)$, and calcium sulphate $\left(\mathrm{CaSO}_{4}\right)^{11}$. The $\mathrm{Na}_{2} \mathrm{SO}_{4}$ arises mostly from the reaction of sodium chloride $(\mathrm{NaCl})$ with $\mathrm{H}_{2} \mathrm{SO}_{4}$ that comes mainly from marine biological activity ${ }^{12}$. The $\mathrm{CaSO}_{4}$ arises from terrestrial gypsum and also from a reaction in aerosol between $\mathrm{H}_{2} \mathrm{SO}_{4}$ and calcium carbonate ${ }^{12}$. These salts primarily form during their transport through the atmosphere ${ }^{13}$. Once in the ice, sulphate salts are good proxies for past atmospheric chemistry because, unlike the more mobile, volatile compounds such as $\mathrm{HNO}_{3}$ (ref. 14) and liquid $\mathrm{H}_{2} \mathrm{SO}_{4}$ (ref. 10), they are largely unaffected by post-depositional processes. 
Analyses ${ }^{5,15}$ of the sulphate-ion $\left(\mathrm{SO}_{4}{ }^{2-}\right)$ record in Antarctic ice cores show that almost all non-sea-salt sulphate ions in inland Antarctic ice cores come from marine biological activity ${ }^{15}$. However, because the ice samples were melted before measurement, those studies could not definitively separate the sulphuric-acid $\left(\mathrm{H}_{2} \mathrm{SO}_{4}\right)$ flux from the sulphate-salt $\left(\mathrm{Na}_{2} \mathrm{SO}_{4}\right.$ and $\left.\mathrm{CaSO}_{4}\right)$ flux. Even less is known about how much of the sulphate salt mixed with silicate mineral dust. Here, we present a complete record of the sulphate salt and sulphate-adhered dust fluxes to inland Antarctica over the past $300 \mathrm{kyr}$.

To determine the sulphate-salt and sea-salt $(\mathrm{NaCl})$ fluxes, we combined two methods: i) an ion-analysis method ${ }^{11}$, here applied to the $300-$ kyr record in the Dome Fuji ice core, and ii) elemental and compositional analysis of single particles extracted from the same ice record, using a sublimation method ${ }^{13,16}$.

We found that particles (Fig. S2) in glacial inceptions and interglacial periods can be distinguished from those in glacial maxima by their values of $\mathrm{Na}_{2} \mathrm{SO}_{4} / \mathrm{CaSO}_{4}$ and $\mathrm{NaCl} / \mathrm{Na}_{2} \mathrm{SO}_{4}$. During glacial maxima, $\mathrm{Na}_{2} \mathrm{SO}_{4} / \mathrm{CaSO}_{4}$ values are particularly low, whereas $\mathrm{NaCl} / \mathrm{Na}_{2} \mathrm{SO}_{4}$ values are high (Fig. 1). With $\mathrm{r}^{2}=0.76$ and a regression slope close to $1\left(0.85 \pm 0.17\right.$ in Fig. S3), the $\mathrm{Na}_{2} \mathrm{SO}_{4} / \mathrm{CaSO}_{4}$ mass ratio correlates well to that from the ion chromatograph (IC) analyses. Since the ion-deduced $\mathrm{CaSO}_{4}$ flux is well-confirmed from the relation between $\mathrm{Ca}^{2+}$ and particle components ${ }^{16,17}$ in the Dome Fuji ice core, we can confidently use the ion-deduced $\mathrm{Na}_{2} \mathrm{SO}_{4}$ and $\mathrm{CaSO}_{4}$ fluxes. 
The regression slope of $\mathrm{NaCl} / \mathrm{Na}_{2} \mathrm{SO}_{4}$ equals 0.84 (Fig. S3), which, considering the $\mathrm{Na}_{2} \mathrm{SO}_{4} / \mathrm{CaSO}_{4}$ slope of 0.85 , indicates that the IC method underestimated the $\mathrm{NaCl}$ flux by up to $29 \%(1-0.85 \times 0.84)$. This underestimate may be due to a poor understanding of mixed nitrate and chloride salt formation. Nevertheless, the high correlation $\left(r^{2}=0.73\right)$ suggests that the $\mathrm{NaCl}$ variations during the 300-ka time-series can be reconstructed well.

The resulting IC-derived $\mathrm{CaSO}_{4}$ and $\mathrm{NaCl}$ fluxes to the ground surface vary significantly over the past $300 \mathrm{kyr}$, both showing high values during glacial maxima (Fig. 2). The high $\mathrm{CaSO}_{4}$ flux agrees with the high dust flux from South America during these stages ${ }^{6,18}$, which suggests that the higher dust flux increases $\mathrm{Ca}^{2+}$ sulphatization, and thus consumes more $\mathrm{H}_{2} \mathrm{SO}_{4}$ in the atmosphere ${ }^{19}$.

During interglacials, both the $\mathrm{NaCl}$ and the $\mathrm{Na}_{2} \mathrm{SO}_{4}$ fluxes are low, probably because the reaction between $\mathrm{NaCl}$ and $\mathrm{H}_{2} \mathrm{SO}_{4}$ to produce $\mathrm{Na}_{2} \mathrm{SO}_{4}$ was limited by the low $\mathrm{NaCl}$ flux ${ }^{10,19}$. Moreover, the $\mathrm{NaCl} / \mathrm{Na}_{2} \mathrm{SO}_{4}$ ratio is low during interglacials and glacial inceptions, but high in glacial maxima (Fig. 1), a trend predicted by the $\mathrm{NaCl}-\mathrm{H}_{2} \mathrm{SO}_{4}$ reaction ${ }^{19}$. A low ratio in interglacials and glacial inceptions indicates excess $\mathrm{H}_{2} \mathrm{SO}_{4}$ in the Antarctic atmosphere (Fig. 2), causing the sulphate-salt flux to be controlled mainly by sea-salt flux ${ }^{10,11}$. In contrast, a high ratio in glacial maxima indicates excess sea-salt flux ${ }^{11}$, causing the sulphate-salt flux to be controlled mainly by $\mathrm{H}_{2} \mathrm{SO}_{4}$ flux. Consistent with this interpretation, we measured very little $\mathrm{H}_{2} \mathrm{SO}_{4}$ during 
glacial maxima (Fig. 2), as nearly all $\mathrm{SO}_{4}{ }^{2-}$ was associated with sulphate salt. In contrast, during interglacial periods and glacial inceptions, the $\mathrm{H}_{2} \mathrm{SO}_{4}$ contribution is relatively high, meaning that the $\mathrm{SO}_{4}{ }^{2-}$ flux is not a good measure of the sulphate-salt flux during these periods.

We also estimated the flux of "sulphate-adhered dust", which are particles with both $\mathrm{Si}$ and sulphate. Such particles likely act as cloud condensation nuclei $(\mathrm{CCN})^{8,20}$, and thus influence climate. We refer to all particles containing Si as "total dust", which are often measured in ice-core studies ${ }^{6,18}$. Since the total dust flux correlates to the non-sea-salt calcium-ion flux ${ }^{5,6}$, we examined the time variation of the ratio of sulphate-adhered dust to total dust versus the ratio of sulphate-salt flux to non-sea-salt calcium-ion flux (Fig. S4). These ratios correlate, both being high during glacial inceptions but low during glacial maxima. We use this correlation together with the measured total-dust flux from the melt samples to obtain the sulphate-adhered dust flux. The sulphate-adhered dust flux averages $0.10 \mathrm{mg} \mathrm{m}^{-2} \mathrm{yr}^{-1}$ through glacial and interglacial periods (Fig. 3a). This constant trend occurs despite the total dust flux increasing by a factor of 50 (up to $\sim 5 \mathrm{mg} \mathrm{m}^{-2} \mathrm{yr}^{-1}$ ) between interglacials and glacial maxima. Because of the constant trend, no significant correlation occurs between temperature and sulphate-adhered dust flux, suggesting that the sulphate-adhered dust has little influence on the glacial and interglacial temperature changes via the indirect effect of CCN. 
In contrast to the sulphate-adhered dust, the sulphate-salt flux (another measure of $\mathrm{CCN}$ ) correlates inversely to $\delta^{18} \mathrm{O}$, a temperature proxy (Fig. 3b). This correlation suggests a coupling between temperature and particulate sulphur (through $\mathrm{Na}_{2} \mathrm{SO}_{4}$ and $\left.\mathrm{CaSO}_{4}\right)$. The higher sulphate-salt flux at lower temperature also contrasts with the $\mathrm{SO}_{4}{ }^{2-}$ flux, which shows no clear correlation to temperature ${ }^{5}$. For the relatively warm interglacial periods, including the present Holocene, the evidence here suggests that $\mathrm{Na}_{2} \mathrm{SO}_{4}$ is generally controlled by the flux of sea salt from the ocean, which is relatively low. But in glacial maxima, the sea-salt and dust fluxes increase, leading to greater particulate sulphur flux. (The flux of sulphate salt exceeds that of $\mathrm{SO}_{4}{ }^{2-}$ because the salt has a higher molar weight). During such cold periods, the amount of particulate sulphur is limited by the amount of $\mathrm{SO}_{4}{ }^{2-}$. This $\mathrm{SO}_{4}{ }^{2-}$ comes from marine biogenic sulphur $^{15}$, and thus marine biological activity influences the amount of sulphate salt.

The coupling shown here between temperature and sulphate-salt flux provides new evidence to examine the long-debated ${ }^{4}$ CLAW hypothesis $^{3}$. In the CLAW hypothesis, marine biogenic sulphur provides a negative feedback to climate change. As such, the CLAW feedback requires both a controlling effect of this sulphur on CCN production and a response of the biogenic sulphur production to climate. Concerning the first requirement, a recent review ${ }^{4}$ shows that sulphur does not control $\mathrm{CCN}$ in the present interglacial period. Our evidence from the three most recent interglacials agrees with this view because our data indicates that sea salt rather than marine sulphur 
controls particulate sulphate flux. On the other hand, during glacial maxima, the greater sulphate-salt flux is determined by the marine-sulphur flux, which agrees with the first requirement. However, the CLAW negative feedback requires that the greater sulphate-salt flux decreases marine sulphur emissions as a consequence of changes in cloud albedo and surface temperature, which is inconsistent with our finding that $\mathrm{SO}_{4}{ }^{2-}$ flux does not decrease during glacial maxima (Fig. 3). Thus, the CLAW requirement appears to fail even during glacial maxima.

The correlation between temperature and sulphate salts suggests that the sulphate salts have an indirect aerosol effect on glacial-interglacial temperature changes. To obtain a rough estimate of the radiative forcing caused by the flux change of sulphate salt, we use recent radiative modelling results. To use the results, we i) note that the Holocene-to-LGM sulphate-concentration ratio roughly equals the corresponding ratio of the pre-industrial-to-present anthropogenic sulphate emissions ${ }^{21,22}$ (see Fig. S5), and ii) assume that the sulphate-salt concentration changes globally. This assumption is consistent with the finding that the change of dust flux in Antarctica correlates strongly to global dust flux ${ }^{23}$.

The resulting model gives a net radiative cooling in the LGM from the sulphate of -1.85 (ref. 24) and -2.57 (ref. 25) $\mathrm{W} / \mathrm{m}^{2}$, producing a global climate cooling of 0.10 and $2.24 \mathrm{~K}$. By applying the polar-amplification factor $^{26}(1.3-2.3)$, the resulting cooling in Antarctica ranges from 0.1 to $5.2 \mathrm{~K}$ just due to the indirect aerosol effect. The value 
$5.2 \mathrm{~K}$ is likely overestimated because other reports ${ }^{2}$ suggest lower radiative cooling. Considering that the temperature change between the LGM and Holocene in Antarctica is $\sim 8^{\circ} \mathrm{C}^{26}$, our estimate highlights the large uncertainty in the climatic impact of indirect aerosol effects from sulphate salts. Thus, the role of sulphate salts and sulphate-adhered dust as the indirect effect should be quantified using paleoclimate models with our new aerosol data and other proxies (e.g., temperature, $\mathrm{CO}_{2}, \mathrm{CH}_{4}$, total dust) archived in the ice core.

\section{Methods Summary}

To determine the amount of sulphate, chloride, and mineral particles in the Dome Fuji ice core, we used our recently developed low-temperature sublimation and particle-analysis $\operatorname{method}^{13,} 16$ and compared the results to analysis ${ }^{11}$ on ion chromatography (IC) data obtained earlier ${ }^{27}$. The analysis of the IC data determines the salt fluxes of $\mathrm{CaSO}_{4}, \mathrm{Na}_{2} \mathrm{SO}_{4}$ plus $\mathrm{MgSO}_{4}$, and $\mathrm{NaCl}$ plus $\mathrm{MgCl}_{2}$ from ion concentrations. Results from the two methods agreed well for $\mathrm{CaSO}_{4}$ and the $\mathrm{Na}_{2} \mathrm{SO}_{4}$ plus $\mathrm{MgSO}_{4}$ fluxes (Fig. S3).

The sublimation method removes volatiles such as $\mathrm{H}_{2} \mathrm{O}, \mathrm{HCl}, \mathrm{HNO}_{3}$, and $\mathrm{H}_{2} \mathrm{SO}_{4}{ }^{13}, 16$. In all, we sublimated 38 sampled sections over the $300-\mathrm{kyr}$ period and analysed them using scanning electron microscopy (SEM) / energy dispersive spectroscopy (EDS). Each sample yielded several hundred particles exceeding 0.4- $\mu \mathrm{m}$ 
diameter (total: 16,821). To determine if the particles had a mineral, a sulphate, or a chloride component, we used a scheme from previous studies ${ }^{13,16}$ that divides nonvolatile particles into insoluble and soluble components. We assumed that $\mathrm{Na}$ and $\mathrm{S}$ in a given particle came from $\mathrm{Na}_{2} \mathrm{SO}_{4}$, whereas $\mathrm{Na}$ and $\mathrm{Cl}$ came from $\mathrm{NaCl}$, and $\mathrm{Ca}$ and $\mathrm{S}$ from $\mathrm{CaSO}_{4}$. Then, we calculated the mass ratios of $\mathrm{Na}_{2} \mathrm{SO}_{4}$ to $\mathrm{NaCl}$ and of $\mathrm{Na}_{2} \mathrm{SO}_{4}$ to $\mathrm{CaSO}_{4}$ following the method described in ref. 16. To obtain the number ratio of sulphate-adhered dust to total silicate dust particles, we assumed that a particle with both $\mathrm{S}$ and $\mathrm{Si}$ was sulphate-adhered dust and divided the number $(\mathrm{N}(\mathrm{S} \cap \mathrm{Si}))$ by the total number of particles with $\mathrm{Si}(\mathrm{N}(\mathrm{Si}))$. Supplementary Data file lists the uncertainties.

\section{References}

1 Jansen, E. et al. in Climate Change 2007: The Physical Science Basis. Contribution of Working Group I to the Fourth Assessment Report of the Intergovernmental Panel on Climate Change (eds Solomon, S. et al.) 433-498 (Cambridge University Press, Cambridge, 2007)

2 Forster, P. et al. in Climate Change 2007: The Physical Science Basis. Contribution of Working Group I to the Fourth Assessment Report of the Intergovernmental Panel on Climate Change (eds Solomon, S. et al.) 129-234 (Cambridge University Press, Cambridge, 2007)

3 Charlson, R. J., Lovelock, J. E., Andreae, M. O. \& Warren, S. G. Oceanic 
phytoplankton, atmospheric sulphur, cloud albedo, and climate. Nature 326, 655-661 (1987)

4 Quinn, P. K. \& Bates, T. S. The case against climate regulation via oceanic phytoplankton sulphur emissions. Nature 480, 51-56 (2011)

5 Wolff, E. W. et al. Southern Ocean sea-ice extent, productivity and iron flux over the past eight glacial cycles. Nature 440, 491-496 doi:10.1038/nature04614 (2006)

6 Lambert, F. et al. Dust climate couplings over the past 800,000 years from the EPICA Dome C ice core. Nature 452, 616-619 doi:10.1038/nature06763 (2008)

7 EPICA community members. Eight glacial cycles from an Antarctic ice core. Nature 429, 623-628 (2004)

8 Andreae, M. O. et al. Internal mixture of sea salt, silicates, and excess sulfate in marine aerosols. Science 232, 1620-1623 (1986)

9 Bodhaine, B. A. Aerosol absorption measurements at Barrow, Mauna Loa and the South Pole. J. Geophys. Res. 100, D5, 8967-8975 (1995)

10 Iizuka, Y., Hondoh, T. \& Fujii, Y. $\mathrm{Na}_{2} \mathrm{SO}_{4}$ and $\mathrm{Mg}_{2} \mathrm{SO}_{4}$ salts during the Holocene period derived by high-resolution depth analysis of a Dome Fuji ice core. $J$. Glaciol. 52 (176), 58-64 (2006)

11 Iizuka, Y. et al. A relationship between ion balance and the chemical compounds of salt inclusions found in the GRIP and Dome Fuji ice cores. J. Geophys. Res. 113, D07303, doi:10.1029/2007JD009018 (2008) 
12 Legrand, M. R., Lorius, C., Barkov, N. I. \& Petrov, V. N. Vostok (Antarctica) ice core: atmospheric chemistry changes over the last climatic cycle $(160,000$ years). Atmos. Environ. 22, 317-331 (1988)

13 Iizuka, Y. et al. The rates of sea salt sulfatization in the atmosphere and surface snow of inland Antarctica. J. Geophys. Res. 117, D04308, doi:10.1029/2011JD016378 (2012)

14 Röthlisberger, R. et al. Nitrate in Greenland and Antarctic ice cores: a detailed description of post-depositional processes. Ann. Glaciol. 35, 209-216 (2002)

15 Kaufmann, P. et al. Ammonium and non-sea salt sulfate in the EPICA ice cores as indicator of biological activity in the Southern Ocean. Quaternary Sci. Rev. 29 (1-2), 313-323 (2010)

16 Iizuka, Y. et al. Constituent elements of insoluble and nonvolatile particles during the Last Glacial Maximum of the Dome Fuji ice core. J. Glaciol. 55 (191), $552-562(2009)$

17 Sakurai, T. et al. The chemical forms of water-soluble microparticles preserved in the Antarctic ice sheet during Termination I., J. Glaciol. 57 (206), 1027-1032 (2011)

18 Delmonte, B. et al. Aeolian dust in East Antarctica (EPICA-Dome C and Vostok): provenance during glacial ages over the last 800 kyr. Geophys. Res. Lett. 35, L07703 doi:10.1029/2008GL033382 (2008) 
19 Röthlisberger, R. et al. Limited dechlorination of sea salt aerosols during the last glacial period: evidence from the EPICA Dome C ice core. J. Geophys. Res. 108, D16, doi:10.1029/2003JD003604 (2003)

20 Manktelow, P. T., Carslaw, K. S., Mann, G. W. \& Spracklen, D. V. The impact of dust on sulfate aerosol, $\mathrm{CN}$ and $\mathrm{CCN}$ during an East Asian dust storm. Atmos. Chem. Phys. 10, 365-382 (2010)

21 Penner, J. E. et al. in Climate Change 2001, Working Group I: The Scientific Basis (eds Houghton, J. T. et al.) 289-348 (Cambridge University Press, Cambridge, 2001)

22 Fujii, Y. et al. 210-year ice core records of dust storms, volcanic eruptions and acidification at Site-J, Greenland. Mem. Natl Inst. Polar Res., Spec. Issue 54, 209-220 (2001)

23 Winckler, G. et al. Covariant glacial-interglacial dust fluxes in the equatorial pacific and Antarctica. Science 320, 93-96 doi: 10.1126/science.1150595 (2008)

24 Tsai, I. C. et al. Sulfur cycle and sulfate radiative forcing simulated from a coupled global climate-chemistry model. Atmos. Chem. Phys. 10, 3693-3709 (2010)

25 Lohmann, U. \& Feichter, J. Global indirect aerosol effects: a review. Atmos. Chem. Phys. 5, 715-737 (2005)

26 Masson-Delmotte, V. et al. Past and future polar amplification of climate change: climate model intercomparisons and ice-core constraints. Clim. Dyn. 26, 
513-529 doi:10.1007/s00382-005-0081-9 (2006)

27 Watanabe, O. et al. General tendencies of stable isotopes and major chemical constituents of the Dome Fuji deep ice core. Mem. Natl Inst. Polar Res., Spec. Issue 57, 1-24 (2003)

28 Fujii, Y., Kohno, M., Matoba, S., Motoyama, H. \& Watanabe, O. A 320 k-year record of microparticles in the Dome Fuji, Antarctica ice core measured by laser-light scattering. Mem. Natl Inst. Polar Res., Spec. Issue 57, 46-62 (2003)

Supplementary Information accompanies this paper on www.nature.com/nature.

\section{Acknowledgements}

We thank all members of the JARE and Ice Core Consortium for Dome Fuji activities; T.

Takemura, R. Kudo, Y. Fujiyoshi, T. Aoki for technical comments on radiative forcing of aerosols; H. Ohno, T. Sakurai for technical comments on micro particles in Dome Fuji ice core. K. Goto-Azuma, T. Kuramoto, H. Yamada for data management of ion and dust concentrations in Dome Fuji ice core; Y. Fujii for data provided of ion concentrations in Site J firn core to calculate sulphate salts. Y. I. thanks to M. Furusaki for the EDS analyses support; J. Nelson for manuscript revision support. This study was supported by Creative Scientific Research (grant number 14GS0202), Young Scientists 
(A) grant number 23680001 and Scientific Research (S) grant number 21221002, provided by the Ministry of Education, Culture, Sports, Science and Technology (MEXT), the Japan Society for the Promotion of Science (JSPS), and by the Grant for Joint Research Program of the Institute of Low Temperature Science, Hokkaido University.

\section{Author Contributions}

Y.I. ran the experiments and analyzed data on statistical methods. Y.I., R.U., T.S, H.M., and T.H. discussed the results and commented on the manuscript. T.M. and M.H. provided the dust and ion data. Y.I. and R.U. wrote the paper. Y.I., H.M., and T.H. supported financial resources.

\section{Author Information}

Reprints and permissions information is available at www.nature.com/reprints. The authors declare no competing financial interests. Correspondence and requests for materials should be addressed to Y.I. (iizuka@lowtem.hokudai.ac.jp)

\section{Figure Legends}

Figure 1 | Oxygen isotope and salt mass ratios of the past $300 \mathrm{kyr}$ before present 
(AD 2,000) in the Dome Fuji ice core. a, Oxygen isotope ratio of ice (expressed as $\delta^{18} \mathrm{O}$ with VSMOW reference) from ref. $27(\mathrm{n}=691$, uncertainty below $0.1 \%$ ). Gray bars indicate glacial maxima (the Marine Isotope Stages of 2, 4, 6b, 6d, 6f, 8d). b, Salt mass ratio $\mathrm{Na}_{2} \mathrm{SO}_{4} / \mathrm{CaSO}_{4}$ from the EDS method (single-particle analysis) on 38 filter samples (solid circles) and measured from ion concentrations (ref. 27) of 691 melt samples (line). Vertical error bars are uncertainties (i.e., coefficient of variation) in the EDS ratios. Numerical values are in Supplementary Data. Uncertainty in the ion-deduced ratios ranges from 36 to $49 \%$ for average glacial and interglacial conditions. c, Same as b except for the $\mathrm{NaCl} / \mathrm{Na}_{2} \mathrm{SO}_{4}$ salt mass ratio. Uncertainty in the ion-deduced ratios ranges from 34 to $19 \%$ for average glacial and interglacial conditions.

Figure 2 Sulphate ion and salts fluxes. a, Isotopic data as in panel a of Fig. 1. The Marine Isotope Stages $1-8 \mathrm{e}$ are indicated at top. Open boxes $(1,5 \mathrm{e}, 7 \mathrm{e})$ are interglacials, arrows $(5 \mathrm{~d}, 7 \mathrm{~d})$ are glacial inceptions, and filled boxes $(2,4,6 \mathrm{~b}, 6 \mathrm{~d}, 6 \mathrm{f}$, 8d) are glacial maxima. b, $\mathrm{NaCl}$ flux from ion concentration measurements (ref. 27) after being verified by the single-particle (EDS) measurements. Uncertainty of the $\mathrm{NaCl}$ flux is $17 \%$ for average glacial conditions and $10 \%$ for interglacial conditions. c, Cumulative salt fluxes from ion concentration measurements (ref. 27) after being verified by EDS measurements. $\mathrm{Na}_{2} \mathrm{SO}_{4}$ is blue and $\mathrm{CaSO}_{4}$ orange. The $\mathrm{Na}_{2} \mathrm{SO}_{4}$ flux 
uncertainty ranges from 17 to $10 \%$ for average glacial and interglacial conditions; the corresponding values for $\mathrm{CaSO}_{4}$ range from 19 to $39 \%$. d, The sulphate-ion $\left(\mathrm{SO}_{4}{ }^{2-}\right)$ flux (from ref. 27). Uncertainty in the $\mathrm{SO}_{4}{ }^{2-}$ flux ranges from 17 to $5.7 \%$ for average glacial and interglacial conditions. e, Fractional contribution of sulphuric acid $\left(\mathrm{H}_{2} \mathrm{SO}_{4}\right)$ and sulphate salt $\left(\mathrm{Na}_{2} \mathrm{SO}_{4}\right.$ plus $\left.\mathrm{CaSO}_{4}\right)$ to the total sulphur flux.

Figure 3 | Correlations of relevant fluxes to the temperature proxy $\delta^{18} \mathrm{O}$. a, Sulphate-adhered and total dust fluxes (from ref. 28). The uncertainty of the sulphate-adhered dust flux ranges from 31 to $58 \%$ for average glacial and interglacial conditions; the corresponding values for the total dust flux are 17 to $14 \%$. b, Sulphate-ion and sulphate-salt fluxes. The linear fitting line for the salt is $\mathrm{F}_{\mathrm{SALT}}=-0.44$ $\delta^{18} \mathrm{O}-20.9$ with $\mathrm{r}^{2}=0.42(\mathrm{n}=691)$. The correlation is significant with a $\mathrm{P}$ value below 0.001 . (For the ion, a linear fit gives an $\mathrm{R}^{2}$ of only 0.005 ). Uncertainty of the sulphate-ion flux ranges from 17 to $5.7 \%$ for average glacial and interglacial conditions; for the sulphate-salt flux, the range is 17 to $12 \%$. 




Fig. 1, Nature manuscript 2012-01-01306C 

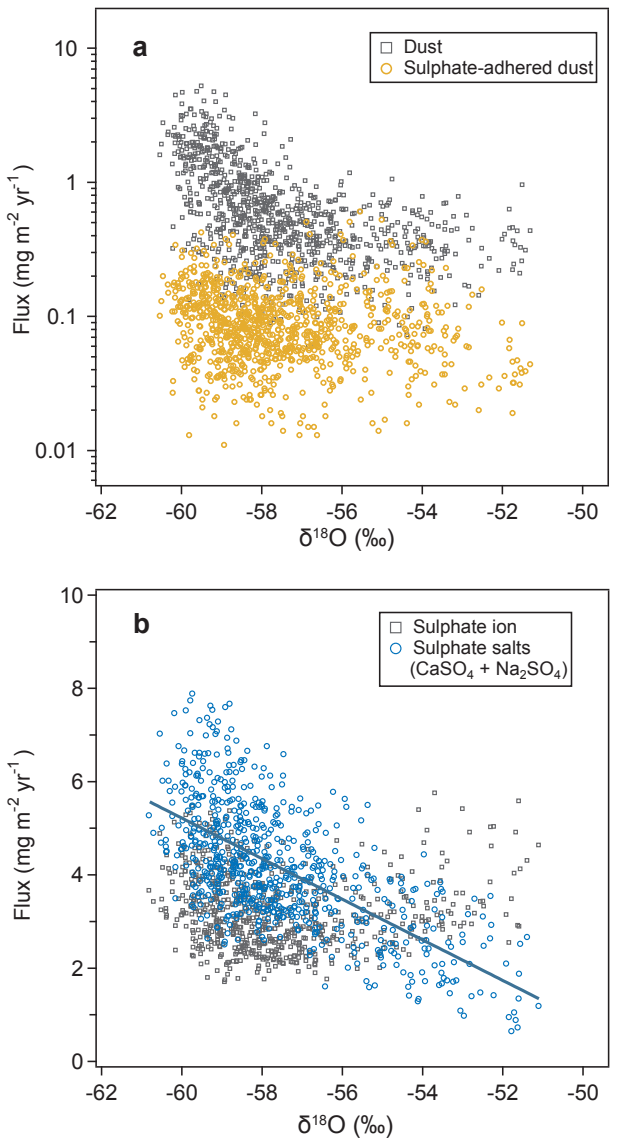

Fig. 3, Nature manuscript 2012-01-01306C 